\title{
Influence of water regime on initial growth and essential oil of Eucalyptus globulus
}

\author{
Túlio Barroso Queiroz' ${ }^{\prime *}$ Nayara Natacha de Jesus Pereira' Júlio Cesar Rodrigues Lopes Silva' \\ Francine Souza Alves da Fonseca' Ernane Ronie Martins'
}

${ }^{1}$ Laboratório de Plantas Medicinais e Aromáticas, Instituto de Ciências Agrárias da Universidade Federal de Minas Gerais (ICA/UFMG), Av. Universitária, 1000, Bairro Universitário, 39404-547, Montes Claros, MG, Brasil. E-mail: tulio-bq@hotmail.com. "Corresponding author.

ABSTRACT: Understanding the water requirement of forest species in the seedling stage supports cost reduction by eliminating unnecessary irrigation in addition to providing higher productivity. This study was carried out to evaluate the effect of the water regime on initial growth, leaf production and content and chemical composition of the essential oil of Eucalyptus globulus, during the first 120 days of cultivation. The experiment employed a completely randomized design and was carried out at the Instituto de Ciencias Agrárias da Universidade Federal de Minas Gerais (ICA/UFMG), Montes Claros, MG. Treatments consisted of six different water regimes $(50 \%, 75 \%, 100 \%, 125 \%, 150 \%$ and $175 \%$ of the reference evapotranspiration - ETo) with four replicates. Plant growth was evaluated by measuring linear dimensions - height, stem diameter and number of leaves. The essential oil was extracted from fresh leaves by hydrodistillation in a Clevenger apparatus. The present study demonstrated that irrigation depths corresponding to $75 \%$ of the ETo are responsible for increased growth of $\boldsymbol{E}$. globulus and increased dry matter production of leaves. The lowest irrigation levels were responsible for the greatest essential oil content. The essential oil was analyzed by gas chromatography-mass spectrometry (CG-MS), and eucalyptol (40.84\% to 55.72\%) was reported to be the major compound for all treatments. Compounds such as $\beta$-myrcene, $\alpha$-Gurgujeno, Alloromadendreno, Varidiflorene appear under specific irrigation conditions. Key words: Eucalyptus, Irrigation, Water stress, Eucalyptus globulus.

\section{Influência do regime hídrico sobre o crescimento inicial e óleo essencial de Eucalyptus globulus}

\begin{abstract}
RESUMO: Conhecer a exigência hídrica de espécies florestais na fase de muda, além de proporcionar maior produtividade, possibilita reduzir custos, eliminando irrigações desnecessárias. Este estudo foi realizado com o objetivo de avaliar o efeito dos regimes hídricos no crescimento inicial, produção de folhas, teor e composição química do óleo essencial de Eucalyptus globulus, nos primeiros 120 dias de cultivo. O trabalho foi conduzido no Instituto de Ciências Agrárias da Universidade Federal de Minas Gerais (ICA/UFMG), Montes Claros, MG, empregando o delineamento inteiramente casualizado. Os tratamentos consistiram em seis regimes hídricos $(50 \%, 75 \%, 100 \%, 125 \%$, 150\% e 175\% da Evapotranspiração de referência - ETo), com quatro repetições. O crescimento das plantas foi avaliado por meio de dimensões lineares - altura, diâmetro do coleto e número de folhas. O óleo essencial foi extraído das folhas frescas e obtido pelo processo de hidrodestilação, em aparelho Clevenger. Neste estudo, foi observado que lâminas de irrigação correspondentes a 75\% da ETo são responsáveis por maior crescimento do $\boldsymbol{E}$. globulus e maior produção de matéria seca das folhas. As menores lâminas de irrigação foram responsáveis pelos maiores teores de óleo essencial. Óleo essencial foi analisado por cromatografia gasosa acoplada à espectrometria de massas (CG-EM), e apontou o eucaliptol (40,84 a 55,72\%) como composto majoritário para todos os tratamentos. Os compostos como $\beta$-mirceno, $\alpha$-Gurgujeno, Alloromadendreno e Varidiflorene apareceram em condições especificas de irrigação. Palavras-chave: eucalipto, irrigação, estresse hídrico, Eucalyptus globulus.
\end{abstract}

\section{INTRODUCTION}

In the implementation of forest species in the field, the growth, development and initial survival of plants occur in response to the quality of the seedlings in the nursery (TUCCI et al., 2011). Brazilian forestry industry has made progress under the most diverse water availability conditions; however, productivity gain is directly related to the availability of this resource in the soil (STAPE et al., 2010). The water regime affects: the sap flow, nutrient distribution, stomatal conductance (CARTER\& WHITE 2009), net photosynthesis rate, transpiration, leaf water potential (VELLINI et al., 2008) height, diameter of the stem diameter and the number of leaves
(MARTINS et al., 2008). Studies have assessed the effects of water availability on productivity of forest species such as Swietenia macrophylla (MORRIS et al., 2000), Mimosa caesalpiniifolia, Enterolobium contortisiliquum, Prosopis juliflora and Tabebuia aurea (SILVA\& NOGUEIRA, 2003), Eucalyptus urograndis (STAPE et al., 2004; SAAD et al., 2009) Eucalyptus grandis (LOPES et al., 2005a), Khaya senegalensis (ALI et al., 2013), Erythrina falcata (PELEGRINI et al., 2013), Eucalyptus urophylla (OUYANG et al., 2016).

Water relations in plants are an important factor to be studied, because of the diversity of physiological and ecological functions of water (KERBAUY, 2008). In addition, with the advance of 
climate change this resource plays an important role in forest plantations, mainly related to its availability (CALDATO\& SCHUMACHER, 2013).

Eucalyptus globulus has two important differences from other eucalyptus species: easy delignification and bleaching, due to the low content of lignin and reduced retention of the polysaccharide Xylan (PASCOAL NETO et al., 2005). Furthermore, in Brazil $\boldsymbol{E}$. globulus is one of the main producers of essential oil with medicinal properties. This is due to the presence of large quantities of cineole, also known as eucalyptol (BIZZO et al., 2009). This study aimed to investigate the water requirement of this species and assess the effects on growth and essential oil extracted from the leaves in the nursery stage.

\section{MATERIAL AND METHODS}

The experiment was conducted in a greenhouse at the Instituto de Ciências Agrárias da Universidade Federal de Minas Gerais (ICA/UFMG), in Montes Claros, located at $16^{\circ} 40^{\prime} 58.5^{\prime}$ "South latitude, $43^{\circ} 50$ ' $25.6^{\prime \prime}$. East longitude and altitude of 626 metres. The climate of the region is characterized as typical tropical, Aw in the Köeppen classification, with summer rains, annual average temperatures between 22 and $24^{\circ} \mathrm{C}$ and average annual rainfall between 1000 and 1200mm (LOPES et al., 2011).

Sowing was carried out in commercial substrate under intermittent misting for 30 days, until transplanting. The experimental plots consisted of 24 vases perforated in the center, with a capacity of 12 liters (average diameter of $18.5 \mathrm{~cm}$ ) arranged in suspended benches. The soil of each experimental plot was saturated with two liters of water and remained covered for three days with plastic bags, to avoid evaporation and reach field capacity.

The soil used as substrate, typical of the Brazilian savanna (Soil Quartzipsamment), underwent a chemical analysis and presented the following characteristics: $\mathrm{pH}(\mathrm{H} 2 \mathrm{O})=5.9$; remaining- $\mathrm{P}=49.10 \mathrm{mg}$ $\mathrm{L}^{-1} ; \mathrm{K}=10 \mathrm{mg} \mathrm{kg}^{-1} ; \mathrm{Ca}^{2+}=0.20 \mathrm{cmol}_{\mathrm{c}} \mathrm{dm}^{-3} ; \mathrm{Mg}^{2+}=0.10 \mathrm{cmol}_{\mathrm{c}}$ $\mathrm{dm}^{-3} ; \mathrm{H}+\mathrm{Al}=1.07 \mathrm{cmol}_{\mathrm{c}} \mathrm{dm}^{-3} ; \mathrm{SB}=0.33 \mathrm{cmol}_{\mathrm{c}} \mathrm{dm}^{-3}$; $\mathrm{V}=23 \%$; organic matter $=1.26 \mathrm{dag} \mathrm{kg}^{-1}$; and sandy soil (44.50dag $\mathrm{kg}^{-1}$ clay). The following nutrients were applied: $\mathrm{N}\left(100 \mathrm{mg} \mathrm{dm}^{-3}\right) ; \mathrm{P}\left(300 \mathrm{mg} \mathrm{dm}^{-3}\right) ; \mathrm{k}\left(100 \mathrm{mg}^{-}\right.$ $\left.\mathrm{dm}^{-3}\right)$; S (40mg dm $\left.\mathrm{m}^{-3}\right)$; B (0.5 $\left.\mathrm{mg} \mathrm{dm}^{-3}\right) ; \mathrm{Zn}\left(5 \mathrm{mg} \mathrm{dm}^{-3}\right)$ and $0.5 \mathrm{mg} \mathrm{dm}^{-3}$ dolomitic limestone.

A completely randomized design was used with six treatments and four replicates. The treatments consisted of six irrigation depths based on reference evapotranspiration (ETo): 0.5 x ETo; 0.75 x ETo; 1.0 x ETo; 1.25 x ETo; 1.5 x 1.75 x ETo ETo.
The ETo was calculated according to the equation of Hargreaves-Samani (BERNARDO et al., 2009).

Maximum and minimum temperatures were measured in the environment of plant growth, to calculate the ETo, in order to determine the irrigation depths, applied to the graduated cylinder. The following characteristics of growth were measured: stem diameter, height, number of leaves of each individual. At the end of the experiment the leaves of plants subjected to the water regime were collected and their essential oil was extracted and analyzed for chemical composition.

After 120 days, the leaves of the plants of each treatment were collected in the morning (7:00) and were transferred while still fresh to the laboratory for medicinal plants of Instituto de Ciências Agrárias da Universidade Federal de Minas Gerais (ICA/UFMG), where they were subjected to hydrodistillation, in a Clevenger appliance, for a period of 2 hours, for extraction of essential oil. The essential oil content was calculated, based on the dry matter in the sample in $g$ of essential oil per $100 \mathrm{~g}$ dry matter. Following biomass stored in forced ventilation oven at $103^{\circ} \mathrm{C}$ until constant weight, the dry mass was obtained.

The chemical composition of the oil was analyzed by gas chromatography (GC) coupled to mass spectrometry (GC/MS), in the laboratory of Instrumental Chemistry of Instituto de Ciências Agrárias da Universidade Federal de Minas Gerais (ICA/UFMG). The Agilent Technologies system (7890A) was coupled to a mass spectrometer (MS 5975C) with HP-5 MS capillary column $(30 \mathrm{~m} \times 0.25 \mathrm{~mm} \times 0.25 \mu \mathrm{m})$ and helium $\left(1 \mathrm{~mL} \mathrm{\textrm {min } ^ { - }}\right.$ $\left.{ }^{1}\right)$ as drag gas. The injector was kept at $220^{\circ} \mathrm{C}$, following a temperature program of $60^{\circ} \mathrm{C}-240^{\circ} \mathrm{C}$ $\left(3^{\circ} \mathrm{C} \mathrm{min}^{-1}\right)$, operating in electronic impact at 70 $\mathrm{eV}$ in a range of 29 to $550(\mathrm{~m} / \mathrm{z})$. The calculations of retention indices were based on injection of the standard of n-alkanes (nC8-nC40). The data generated were analyzed using MSD Chemstation software along with the NIST library (National Institute of Standards and Technology, NIST 2002). The relative abundance (\%) of constituents was calculated, considering the peak area of the chromatogram (CG) and organized according to the order of elution. Compounds listed were those that showed a relative abundance greater than $1 \%$.

Growth characteristics of seedlings and content of essential oil (\%) were subjected to regression analysis and for dry mass the Tukey test was applied $(\alpha=0.05)$, both using the statistical program SAEG-version 9.1 (SAEG, 2007). 


\section{RESULTS AND DISCUSSION}

At the end of 120 days of growth, the depth with $75 \%$ of the ETo, averaging $4.5 \mathrm{~mm} \mathrm{day}^{-1}$ promoted the greatest mean growth in height $(63.75 \mathrm{~cm})$, stem diameter $(6.68 \mathrm{~mm})$ and number of leaves (Figure 1A, $1 \mathrm{~B}, 1 \mathrm{C})$. However, plants receiving the depth with $175 \%$ of the ETo presented lower values.

The application of $50 \%$ of the ETo, the lowest, corresponded to a mean of $3 \mathrm{~mm} /$ day of irrigation, while the greatest, $(175 \%$ of the ETo), corresponded to $10.5 \mathrm{mmday}^{-1}$ (Figure 2A). According to Lopes et al. (2005a), the survival of seedlings of eucalyptus is strongly influenced by the water regime. In addition, the author reported that at temperatures above $30^{\circ} \mathrm{C}$, gross irrigation depths of 6,8 and $10 \mathrm{~mm}$ day $^{-1}$ are not recommended. In a study of Eucalyptus grandis at 108 days after sowing, LOPES et al. (2005b) observed that irrigation depths of 12 and $14 \mathrm{~mm} \mathrm{day}^{-1}$ favored the development and quality of eucalyptus seedlings.

In a study by LOPES et al. (2007), with irrigation depths of $6,8,10,12$ and $14 \mathrm{~mm}^{\text {day }}{ }^{-1}$, it was observed that the increase in height of the aerial part of Eucalypus grandis was proportional to the increase of depth. In this experiment, it was found; however, that greater depths provided lower growth, due to the consideration of daily ETo in the calculation of depths and to sandy soil as substrate. According to PRAVUSCHI et al. (2010), the application of irrigation depths in sandy soil with little water storage capacity results in lower productivity rates when subjected to excessive irrigation. Thus, soils with this behavior present high permeability and a high infiltration rate (FRANCO et al., 2015). Possibly, the lack of organic matter was responsible for the excessive loss of water, since it affects physical properties (AHMED et al., 2015) and accumulation of this resource in the soil (MARCHINI et al., 2015). According to SCHWIDER et al. (2013), in eucalyptus clonal seedlings at 75 days, greater heights can be observed where the level of available water in the soil is between $75 \%$ and $90 \%$ of field capacity.

In the present study, the essential oil content was affected by the water regime. Excess water hindered growth in number of leaves and, consequently, the production of essential oil. Lower depths favored the production of essential oil (Figure 2B). The depth of $50 \%$ ETo, followed by that of $75 \%$, provided the greatest mean content of essential oil, with $4.43 \%$ and $4.09 \%$, respectively. According to Vieira (2004), the essential oil yield of E. globulus, based on dry weight of leaves, is between $0.7 \%$ and 2.4\% . However, LEAL et al. (2001) observed that plants under stress conditions, may present a greater quantity of oil glands responsible for oil production.

Conversely, the greater irrigation depths provided smaller biomass production, insufficient for obtaining oil by hydrodistillation in the Clevenger appliance. According to GRANDIS et al. (2010), plants under conditions of excessive ground water present reduced energy efficiency, since roots under anoxia present difficulties in maintaining the energy flow in the tissues. In addition, MEDRI et al. (2007), studying morphoanatomic changes of Lithrae molleioides, subjected to flooding, that under excessive water conditions, plants presented lower starch content in the stem and lower production of secretory structures.

Figure 2C shows the irrigation depth of $75 \%$ of the ETo, which provided greater mean dry weight of leaves of $\boldsymbol{E}$. globulus $(21.04 \mathrm{~g})$. According to GREGORIO et al. (2008), studying the effect of flooding on the initial growth of Tabebuia heptaphylla, under conditions of hypoxia and anoxia, both the growth of the aerial and roots are reduced.

Analysis of chemical compounds of the essential oil extracted from $\boldsymbol{E}$. globulus, showed different constituents in accordance with the water regime (Table 1). Environmental factors directly influence the chemical makeup of the plant's secondary metabolites, such as radiation, temperature, precipitation, winds, altitude, soil, season and time of collection (LIMA et al., 2003). The compound found in the greatest quantity was eucalyptol for all treatments; however, it presented relative abundance, ranging from 40.84 to $55.72 \%$. The other compounds ( $\alpha$-pinene, limonene, $\alpha$-terpinol and aromadendrene) also showed variation in relative abundance. In addition, the chemical composition of the essential oil showed that plants grown under different irrigation depths may be present limited presence of compounds such as $\beta$-myrcene, $\alpha$-Gurgujene, Varidiflorene, Ledol isomer 1 and $\beta$-Eudesmol. According to CHAVES et al. (2004), studying eucalyptus clones in the seedling stage at 4 months of age, the species may present different adaptations to environments depending on the availability of water. MALINOWSKI (2010), studying the chemical composition of $\boldsymbol{E}$. globulus, in the four seasons (spring, summer, winter and autumn), noted, as was reported in this study, that eucalyptol (1-8 cineole) was the compound found in the greatest quantity, which ranged between 54.42 and $60.35 \%$.

\section{CONCLUSION}

The chemical composition of the essential oil extracted from the leaves and the growth of $\boldsymbol{E}$. 


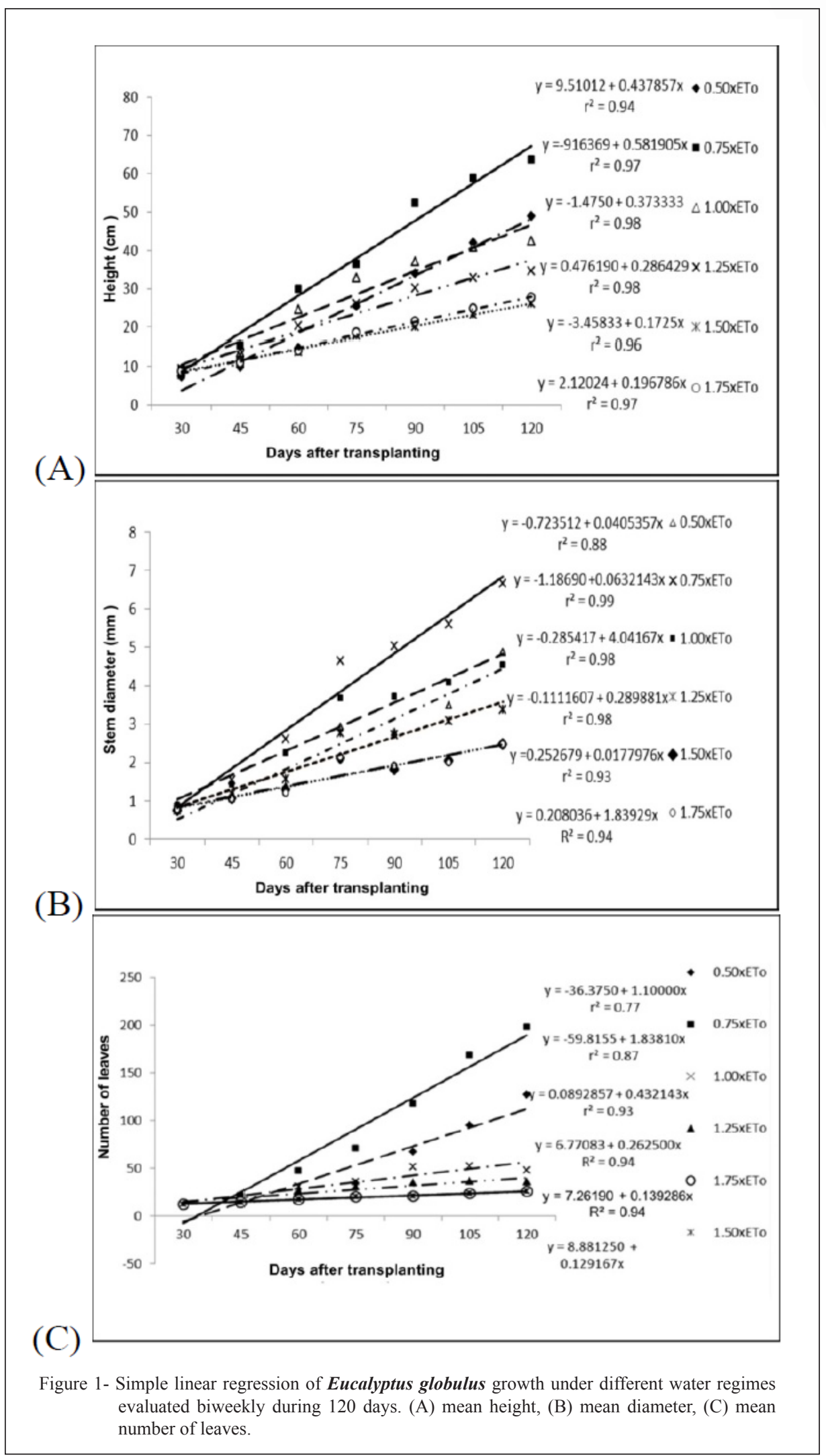

Ciência Rural, v.47, n.3, 2017. 


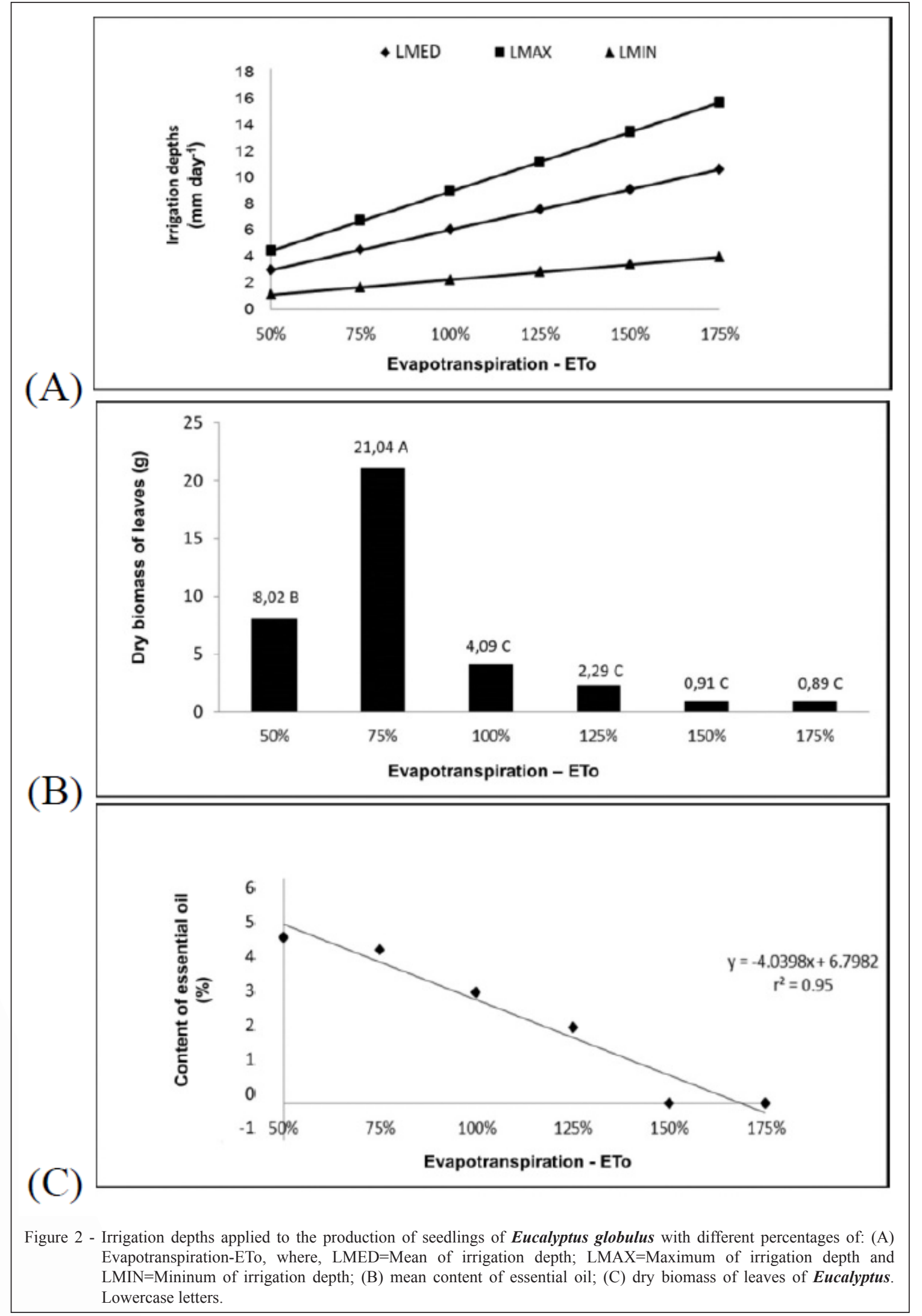

Ciência Rural, v.47, n.3, 2017. 
Table 1 - Chemical composition of essential oil extracted from Eucalyptus globulus grown under four water regimes.

\begin{tabular}{|c|c|c|c|c|c|c|c|c|}
\hline \multirow{2}{*}{$\mathrm{n}^{\circ}$ Peak } & \multirow{2}{*}{ Compound } & \multirow{2}{*}{ RT } & \multirow{2}{*}{$\mathrm{IR}_{\mathrm{cal}}$} & \multirow{2}{*}{ IR } & \multicolumn{4}{|c|}{----------------------Irrigation Depth (ETo)-------------------- } \\
\hline & & & & & $50 \%$ & $75 \%$ & $100 \%$ & $125 \%$ \\
\hline \multicolumn{9}{|c|}{ - } \\
\hline 1 & $\alpha$-Pinene & 5.5 & 931 & 931 & $13.1 \pm 2.2$ & $13.8 \pm 3.7$ & $9.5 \pm 4.0$ & $5.4 \pm 1.3$ \\
\hline 2 & $\beta$-Myrcene & 7.0 & 987 & 993 & nd & $1.1 \pm 0.0$ & nd & $\mathrm{Nd}$ \\
\hline 3 & Limonene & 8.3 & 1028 & 1028 & $6.5 \pm 0.8$ & $6.8 \pm 0.6$ & $5.4 \pm 0.7$ & $4.3 \pm 1.3$ \\
\hline \multicolumn{9}{|c|}{ - } \\
\hline 4 & Eucalyptol & 8.5 & 1032 & 1031 & $47.5 \pm 9.5$ & $55.7 \pm 4.0$ & $42.5 \pm 7.3$ & $40.8 \pm 2.4$ \\
\hline 5 & $\alpha$-Terpineol & 14.8 & 1194 & 1190 & $1.8 \pm 0.7$ & $2.1 \pm 0.9$ & $2.3 \pm 0.6$ & $1.7 \pm 0.0$ \\
\hline 6 & Terpineol Acetate & 21.2 & 1344 & 1343 & $11.8 \pm 3.0$ & nd & $9.0 \pm 1.7$ & nd \\
\hline 7 & Unknown & 22.1 & 1366 & 1357 & nd & $6.2 \pm 2.9$ & nd & $\mathrm{Nd}$ \\
\hline 8 & Geraniol acetate & 22.6 & 1376 & 1376 & nd & $1.3 \pm 0.3$ & $1.3 \pm 0.2$ & $1.5 \pm 0.0$ \\
\hline \multicolumn{9}{|c|}{ - } \\
\hline 9 & $\alpha$-Gurgujene & 23.6 & 1401 & 1408 & nd & nd & nd & $1.0 \pm 0.4$ \\
\hline 10 & Aromadendrene & 24.9 & 1432 & 1439 & $1.7 \pm 0.5$ & $1.7 \pm 0.0$ & $3.8 \pm 2.1$ & $5.8 \pm 1.3$ \\
\hline 11 & Alloroamadendrene & 25.8 & 1454 & 1455 & nd & nd & nd & $1.3 \pm 0.4$ \\
\hline 12 & Varidiflorene & 27.1 & 1485 & 1496 & nd & nd & nd & $2.0 \pm 1.2$ \\
\hline \multicolumn{9}{|c|}{ 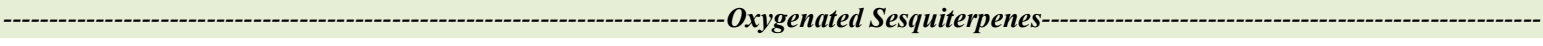 } \\
\hline 13 & Epiglobulol & 29.9 & 1556 & 1532 & nd & nd & $1.4 \pm 0.6$ & $2.2 \pm 0.0$ \\
\hline 14 & Ledol isomer 1 & 30.2 & 1563 & 1551 & nd & nd & nd & $1.4 \pm 0.3$ \\
\hline 15 & Ledol isomer 2 & 30.8 & 1579 & 1569 & $4.1 \pm 1.6$ & $3.9 \pm 1.0$ & $7.9 \pm 2.8$ & $14.1 \pm 1.1$ \\
\hline 16 & Globulol & 31.1 & 1587 & 1580 & $1.2 \pm 0.3$ & nd & $1.7 \pm 0.5$ & $2.9 \pm 0.2$ \\
\hline 17 & Eudesmol & 32.3 & 1617 & 1625 & nd & nd & $1.5 \pm 0.4$ & $2.4 \pm 0.2$ \\
\hline 18 & $\beta$-Eudesmol & 33.4 & 1648 & 1651 & nd & nd & $1.6 \pm 0.7$ & $\mathrm{Nd}$ \\
\hline \multicolumn{5}{|c|}{ - } & 87.8 & 86.3 & 87.9 & 86.9 \\
\hline \multicolumn{5}{|c|}{ Trace elements (below 1\% peak area) } & 12.2 & 7.5 & 12.1 & 13.1 \\
\hline \multicolumn{5}{|c|}{ Monoterpenes } & 19.6 & 21.6 & 15.0 & 9.7 \\
\hline \multicolumn{5}{|c|}{ Oxygenated Monoterpenes } & 61.2 & 59.1 & 55.1 & 44.1 \\
\hline \multicolumn{5}{|c|}{ Sesquiterpenes } & 1.7 & 1.7 & 3.8 & 10.2 \\
\hline \multicolumn{5}{|c|}{ Oxygenated Sesquiterpenes } & 5.3 & 3.9 & 14.1 & 23.0 \\
\hline \multicolumn{5}{|c|}{ Oil Content (\%) } & 4.4 & 4.1 & 2.0 & 2.0 \\
\hline
\end{tabular}

Legend: RT=Retention Time; $\mathbb{R}_{\text {cal }}=$ Index of Calculated Retention; $I R=$ Retention Indexaccording toADAMS, 2007; nd=compound not detected.

globulus are influenced by the water regime. With the conditions described in this experiment, we suggested the application of irrigation depths of $75 \%$ of the ETo in order to provide greater initial growth to seedlings of $\boldsymbol{E}$. globulus. In addition, it was reported that the greatest irrigation depths negatively affected the growth of plants, providing lower content of essential oil in dry matter of leaves.

\section{ACKNOWLEDGMENTS}

The authors would like to thank the Laboratório de Química Instrumental e de Plantas Medicinais e Aromáticas do Instituto de Ciências Agrárias da Universidade Federal de Minas Gerais (ICA-UFMG), Programa de Educação Tutorial, PETAgronomia ICA-UFMG and Fundação de Amparo à Pesquisa do estado de Minas Gerais (FAPEMIG) for support.

\section{REFERENCES}

ADAMS, R. P. Identification of essential oils components by gas chromatography: quadrupole mass spectroscopy. Chicago: Allured Publishing Corporation, 2007. 803p.

ALI, H. M. et al. Performance of forest tree Khaya senegalensis (Desr.) A. Juss. under sewage effluent irrigation. Ecological Engineering, Amsterdan, v.61, p.117-126, 2013. Available from: <http://www. sciencedirect.com/science/article/pii/S0925857413003972>. Accessed: Mar. 20, 2016. doi: 10.1016/j.ecoleng.2013.09.051.

BERNARDO, S. et al. Manual de irrigação. 8. ed. Viçosa: UFV, 2009. 67p.

BIZZO, H. R. et al. Óleos essenciais no Brasil: aspectos gerais, desenvolvimento e perspectivas. Química Nova, São Paulo, v.32, n.3, p.588-594, 2009. Available from: <http://www.scielo.br/ scielo.php?script $=$ sci arttext\&pid $=$ S0100-40422009000300005 $>$. Accessed:Mar. 30,2016. doi: 10.1590/S0100-40422009000300005. 
CADALTO, S. L.; SCHUMACHER, M. V. O uso da água em plantações florestais - Uma revisão. Ciência Florestal, Santa Maria, v.23, n.3, p.507-516, 2013. Available from: <http://cascavel.ufsm. br/revistas/ojs-2.2.2/index.php/cienciaflorestal/article/view/10562>. Accessed: Mar. 30, 2016. doi: 10.5902/1980509810562.

CARTER, J. L.; WHITE, D. A. Plasticity in the Huber value contributes to homeostasis in leaf water relations of a mallee Eucalypt with variation to groundwater depth. Tree Physiology, Oxford, v.29, p.1407-1418, 2009. Available from: <http://treephys. oxfordjournals.org/content/29/11/1407.full $>$. Accessed: Mar. 30, 2016. doi: 10.1093/treephys/tpp076.

CHAVES, J. H. et al. Seleção precoce de clones de eucalipto para ambientes com disponibilidade diferenciada de água no solo: Relações hídricas de plantas em tubetes. Revista Árvore, Viçosa, v.28, n.3, p.333-341, 2004. Available from: <http://www.scielo.br/ scielo.php?script=sci arttext\&pid=S0100-67622004000300003>. Accessed:Mar.30,2016. doi: 10.1590/S0100-67622004000300003.

FRANCO, G. B. et al. Análise da vulnerabilidade à contaminação do aquífero freático e taxa de infiltração do solo da bacia do rio Almada e área costeira adjacente - BA. Revista Brasileira de Geografia Física, Recife, v.08, n.03, p.705-720, 2015. Available from: <http://www.revista.ufpe.br/ rbgfe/index.php/revista/article/view/1126>. Accessed: Mar. 30, 2016.

GRANDIS, A. et al. Respostas fisiológicas de regiões alagadas às mudanças climáticas globais. Revista Brasileira de Botânica, São Paulo, v.33, n.1, p.1-12, 2010. Available from: <http://www.scielo. $\mathrm{br} /$ scielo.php?pid $=\mathrm{S} 0100-84042010000100002 \&$ script $=$ sci abstract\&tlng=pt $>$. Accessed: Mar. 30, 2016. doi: 10.1590/S010084042010000100002 .

GREGÓRIO, T. A. et al. Efeito do alagamento sobre o crescimento inicial de Tabebuia heptaphylla (Vell.) Toledo (Ipê-rosa). Natureza online, Santa Tereza, v.6, n.2, p.91-98, 2008. Available from: $<\mathrm{http}: / / \mathrm{www}$.naturezaonline.com.br/natureza/conteudo/pdf/08 Greg\%C3\%B3rioTAetal_9198.pdf >. Accessed: Mar. 30, 2016.

KERBAUY, G. B. Fisiologia vegetal. 2. ed. Rio de Janeiro: Guanabara Koogan, 2008. 431p.

LEAL, T. C. A. B. et al.Avaliação do efeito da variação estacional e horário de colheita sobre o teor foliar de óleo essencial de capimcidreira (Cymbopogoncitratus (DC) Stapf). Revista Ceres, Viçosa, v.48, n.278, p.445-453, 2001. Available from: <http://www.ceres.ufv. br/ojs/index.php/ceres/article/view/2735>. Accessed: Mar. 30, 2016.

LIMA, H. R. P. et al. Influência dos fatores abióticos na produção e variabilidade de terpenóides em plantas. Revista Floresta e Ambiente, Seropédica v.10, n.2, p.71-77, 2003. Available from: <http://www. floram.org/articles/view/id/4fedb9681eflfa6a4e000004>. Accessed: Mar. 30, 2016.

LOPES, J. L. W. et al. Efeito de lâminas de irrigação na produção de mudas de Eucalyptusgrandis W. (HILL ex. MAIDEN) em substrato de fibra de coco. Irriga, Botucatu, v.10, n.2, p.123-134, 2005b.

LOPES, J. L. W. et al. Efeitos da irrigação na sobrevivência, transpiração e no teor relativo de água na folha em mudas de Eucalyptusgrandis em diferentes substratos. Scientia Forestalis, Piracicaba, n.68, p.97-106, 2005a. Available from: $<$ http://www.ipef. br/publicacoes/scientia/nr68/cap09.pdf > . Accessed: Mar. 30, 2016.

LOPES, L. W. et al. Qualidade mudas de eucalipto produzido sob diferentes lâminas de irrigação e dois tipos de substrato. Revista Árvore,
Viçosa, v.31, n.5, p.835-843, 2007. Available from: $<$ http://www.scielo. $\mathrm{br} /$ scielo.php?script $=$ sci arttext\&pid $=\mathrm{S} 0100-67622007000500007>$. Accessed: Mar. 30, 2016. doi: 10.1590/S0100-67622007000500007.

LOPES, O. D. et al. Determinação do coeficiente de cultura $(\mathrm{kc})$ e eficiência do uso de água do alecrim-pimenta irrigado.Revista Brasileira de Engenharia Agrícola e Ambiental, Campina Grande, v.15, n.5, p.548-553, 2011. Available from: <http://www.scielo.br/ scielo.php?script $=$ sci arttext\&pid=S1415-43662011000600002 $>$. Accessed: Mar. 30, 2016. doi: 10.1590/S1415-43662011000600002.

MALINOWSKI, L. R. L. Morfologia, fitoquímica e atividades biológicas de folhas jovens de Eucalyptus LABILL. Subespécie bicostata (MAIDEN et al.) J. B. KIRKPAT., MYRTACEAE. 2010. 117f. Dissertação (Mestrado em Ciências Farmacêuticas) - Setor de Ciências da Saúde, Universidade Federal do Paraná, PR.

MARCHINI, D. C. et al. Matéria orgânica. Infiltração e imagens tomográficas de Latossolo em recuperação sob diferentes tipos de manejo. Revista Brasileira de Engenharia Agrícola e ambiental, Campina Grande, v.19, n.6, p.574-580, 2015. Available from: <http:// www.scielo.br/pdf/rbeaa/v19n6/1415-4366-rbeaa-19-06-0574. pdf $>$. Accessed: Mar. 30, 2016. doi: 10.1590/1807-1929/agriambi. v19n6p574-580.

MARTINS, F. B. et al. Deficiência hídrica no solo e seu efeito sobre transpiração, crescimento e desenvolvimento de mudas de espécies de eucalipto. Revista Brasileira de Ciência do Solo, Viçosa, v.32, p.1297-1306, 2008. Available from: <http://www.scielo.br/ scielo.php?script=sci_arttext\&pid=S0100-06832008000300037>. Accessed:Mar.30,2016.doi: 10.1590/S0100-06832008000300037.

MEDRI, M. E. et al. Alterações morfoanatômicas em plantas de Lithraea molleoides (Vell.) (Vell.) (Vell.) Engl. submetidas ao alagamento. Acta Scientiarum biological sciences, Maringa, v.29, n.1, p.15-22, 2007. Available from: <http://periodicos.uem. br/ojs/index.php/ActaSciBiolSci/article/view/408>.Accessed: Mar. 30 2016. doi: 10.4025/actascibiolsci.v29i1.408.

MORRIS, M. H. et al. Sowing date, shade, and irrigation affect big-leaf mahogany (Swietenia macrophylla King). Forest Ecology and Management, Amsterdam, v.132, p.173-181, 2000. Available from: $<$ http://www.sciencedirect.com/science/article/pii/ S0378112799002248>. Accessed: Ago. 03, 2016>. doi: 10.1016/ S0378-1127(99)00224-8.

OUYANG, Y. et al. A system dynamic model to estimate hydrological processes and water use in a eucalypt plantation. Ecological Engineering, Amsterdam, v.86, p.290-299, 2016. Available from: $<\mathrm{http}: / / \mathrm{www}$. sciencedirect.com/science/article/pii/ S0925857415302640>. Accessed: Mar. 30, 2016. doi: 10.1016/j. ecoleng.2015.11.008.

PASCOAL NETO, C. P. et al. Química da madeira de Eucalyptusglobulus: especificidades e impacto nos processos de cozimento e de branqueamento. Aviero: CICECO e Departamento de Química, Universidade de Aveiro, 2005. Available from: $<$ http://www.tecnicelpa.com/files/CozimentoBranqueamento. pdf>. Accessed: Mar. 30, 2016.

PELEGRINI, L. L. et al. Efeito do estresse hídrico simulado com nacl, manitol e peg (6000) na germinação de sementes de Erythrinafalcata benth. Ciência Rural, Santa Maria, v.23, n.2, p.513-521, 2013. Available from: <http://cascavel.ufsm.br/ revistas/ojs-2.2.2/index.php/cienciaflorestal/article/view/9295>. Accessed: Mar. 30, 2016. doi: 10.5902/198050989295. 
PRAVUSCHI, P. R. et al. Efeito de diferentes lâminas de irrigação na produção de óleo essencial do manjericão (Ocimumbasilicum L.). Revista Acta Scientiarum. Agronomy, Maringá, v.32, n.4, p.687-693, 2010. Available from: <http://www.redalyc.org/ articulo.oa?id=303026594003 $>$. Accessed: Mar. 30, 2016. doi: 10.4025/actasciagron.v32i4.3160.

SAAD, J. C. C. Manejo hídrico em viveiro e uso de hidrogel na sobrevivência pós-plantio de Eucalyptus urograndis em dois solos diferentes. Revista de Engenharia Agrícola, Jaboticabal, v.29, n.3, p.404-411, 2009. Available from: <http://www.scielo.br/ scielo.php?script=sci_arttext\&pid=S0100-69162009000300007>. Accessed:Mar.30,2016. doi:10.1590/S0100-69162009000300007.

SAEG. SAEG: sistema para análises estatísticas. Viçosa: UFV, 2007. Versão 9.1.

SCHWIDER, Y. S. et al.Efeito do déficit hídrico sobre o crescimento de eucalipto em diferentes condições microclimáticas. Enciclopédia Biosfera, Goiânia, v.9, n.16, p.888-900, 2013. Available from: $<$ http://www.conhecer.org.br/enciclop/2013a/agrarias/EFEITO\%20 DEFICIT\%20HIDRICO.pdf $>$. Accessed: Mar. 30, 2016.

SILVA, E. C.; NOGUEIRA, R. M. C. Crescimento de quatro espécies lenhosas cultivadas sob estresse hídrico em casa de vegetação. Revista Ceres, Viçosa, v.50, n.288, p.203-217, 2003. Available from: <http://www.ceres.ufv.br/ojs/index.php/ceres/ article/view/2949>. Accessed: Mar. 50, 2016.

STAPE, J. L. et al. Water use, water limitation, and water use efficiency in a Eucalyptus plantation. Bosque, (Valdivia), v.25, n.2, p.35-41, 2004. Available from: <http://mingaonline.uach.cl/ pdf/bosque/v25n2/art04.pdf>. Accessed: Mar. 30, 2016.

STAPE, J. L. et al. The Brazil eucalyptus potential productivity project: influence of water, nutrients and stand uniformity on wood production. Forest Ecology Management, Amsterdam, v.259, p.1684-1694, 2010. Available from: <http://www.sciencedirect. com/science/article/pii/S0378112710000186>. Accessed: Mar. 30, 2016. doi: 10.1016/j.foreco.2010.01.012.

TUCCI, C. A. F. et al. Desenvolvimento de mudas de Swietenia macrophylla em resposta a nitrogênio, fósforo e potássio. Revista Floresta, Curitiba, v.41, n.3, p.471-490, 2011. Available from: <http://ojs.c3sl.ufpr.br/ojs/index.php/floresta/ article/viewArticle/24039>. Accessed: Mar. 30, 2016. doi: 10.5380/rf.v41i3.24039.

VELLINI, A. L. T. T. et al. Respostas fisiológicas de diferentes clones de eucalipto sob diferentes regimes de irrigação. Revista Árvore, Viçosa, v.32, n.4, p.651-663, 2008. Available from: $<$ http://www.scielo.br/scielo.php?script=sci arttext\&pid=S0100-67622008000400006>. Accessed: Mar. 30, 2016. doi: 10.1590/S0100-67622008000400006.

VIEIRA, I. G. Estudos caracteres silviculturais e de produção de óleos essenciais de progênies de Corymbia citriodora (HOOK) K.D. HILL \& L. A. S. JOHNSON procedente de Anhembi SP - Brasil, Ex. ATHERTON QLD - Austrália. 2004. 80f. Dissertação (Mestrado em Recursos Florestais) Escola Superior de Agricultura Luiz de Queiroz, Universidade de São Paulo, SP. 